\title{
Typing of Streptococcus mutans strains isolated from caries free and susceptible subjects by multilocus enzyme electrophoresis
}

\author{
Arezoo Tahmourespour ${ }^{1}$, Abdolreza Nabinejad ${ }^{2}$, Hannaneh Shirian $^{3}$, \\ Edvaldo Antonio Ribeiro Rosa ${ }^{4}$, Sanaz Tahmourespour ${ }^{5}$ \\ ${ }^{1}$ Department of Basic Medical Sciences, School of Dentistry, Khorasgan-Isfahan Branch, \\ Islamic Azad University, Isfahan, Iran. \\ ${ }^{2}$ Razi Vaccine \& Serum Research Institute, Isfahan Branch, Vet Dept of Agriculture, \\ Amirhamzeh, Isfahan, Iran. \\ ${ }^{3}$ Biotechnology Lab, Khorasgan, Isfahan branch, Islamic Azad University, Isfahan, Iran. \\ ${ }^{4}$ Pontifícia Universidade Católica do Paraná, Curitiba, PR, Brazil. \\ ${ }^{5}$ Department of Pediatric Dentistry, School of Dentistry, Khorasgan-Isfahan branch, \\ Islamic Azad University, Isfahan, Iran.
}

Submitted: May 24, 2012; Approved: November 13, 2012.

\begin{abstract}
This study was evaluated the clonal diversity of Streptococcus mutans in caries-free and caries-active subjects using MLEE. Strains from caries-free subjects were grouped in a single taxon. Unrooted dendrogram showed that different strains clustered in four different clades, also showed that more than one clonal type can be found in a same individual.
\end{abstract}

Key words: Streptococcus mutans, multilocus enzyme electrophoresis, caries free, caries susceptible, typing.

Streptococcus mutans, which is the primary cariogenic species, plays an important role in the generation of caries. This bacterium is widely investigated in order to determine its role in the cariogenic microbiota (Arakawa et al., 2004; Baca et al., 2008; Becker et al., 2002; Kamiya et al., 2005; Rosa et al., 2006). S. mutans is widely disseminated not only in populations with moderate or high caries prevalence (Alaluusua et al., 1987; Beighton et al., 1987; Li et al., 2011; Napimoga et al., 2004) but also in populations having no or low caries experience (Carlson et al., 1985; Li et al., 2011; Matee et al., 1993; Napimoga et al., 2004).

For epidemiological purposes, establishment of some criteria that may separate two or more different genetic types, so-called clones, as distinct entities with their particularities is necessary. Intra-species genetic heterogenecity can be confirmed by DNA-based methods, such as restriction enzyme analysis (Caulfield et al., 1989), ribotyping (Alaluusua et al., 1996), arbitrary primed polymerase chain reaction (Gronroos and Alaluusua, 2000) and pulsed field gel electrophoresis (Jordan and LeBlane, 2002). Multilocus enzyme electrophoresis (MLEE) has been applied to study the epidemiology of several genera of pathogenic microorganism such as gram-positive, gram-negative bacteria (Baptist et al., 1971; Caugant et al., 1986; Rosa et al., 2006; Schable et al., 1991), mycoplasms (O'Brine et al., 1981; Redmo et al., 2003; Rosa et al., 2005), filamentous fungi (Araujo et al., 1997), yeasts (Naumov et al., 1997; Rosa et al., 2006), and protozoa (Meloni et al., 1988). Gilmour et al. (1987) proposed the use of MLEE to differentiate oral streptococci in some groups as mutans streptococci and sanguinis streptococci. However, the potential of MLEE for $S$. mutans specimen differentiation was evaluated in a few cases (Napimoga et al., 2004; Redmo et al., 2003; Rosa et al., 2005). In this work, such potential was explored, as well as many electrophoresis/revelation systems were screened for the optimization of enzymatic bands detection. The aims of the present study were to evaluate the clonal diversity of $S$. mutans in caries-free and caries-active

Send correspondence to A. Tahmourespour. Assistant Professor of Microbiology, Department of Basic Medical Sciences, School of Dentistry, Khorasgan-Isfahan branch, Islamic Azad University, Isfahan, Iran. E-mail: atahmoures@khuisf.ac.ir. 
subjects and to compare some virulence traits between isolates of these two groups.

The study groups consisted of seven young adults with the mean age of 23 years without regard to sex. There was no history of antibiotic treatment at least 1 month prior to study. Caries-free individuals [DMF (Decayed, Missing, Filled $=0$ ] contained three subjects and the group of caries-susceptible individuals [DMF $=8 \pm 2]$ contained four subjects.

Volunteers were informed not to brush their teeth during the preceding $12 \mathrm{~h}$ and not to drink or eat anything for $2 \mathrm{~h}$ before sampling. Pooled samples of dental plaque were taken with sterile dental curettes from three surfaces of the anterior and posterior teeth. The samples were immediately transferred to $3 \mathrm{~mL}$ of cold brain heart infusion broth (Difco Laboratories, Detroit, Mich.) and were vigorously shaken with a Vortex mixer to disperse the bacteria, then were transferred to a laboratory on ice and cultured immediately.

The serial dilutions of the samples were cultured on Mitis Salivarius Agar (Merck, Germany) supplemented with $2 \%$ sucrose (Synth) and $2.8 \mu \mathrm{g} / \mathrm{mL}$ of bacitracin (Sigma, USA). Plates were incubated at $37^{\circ} \mathrm{C}$ for $48 \mathrm{~h}$ in an atmosphere of $10 \% \mathrm{CO}_{2}$. After purification of $S$. mutans isolates, their identification was done according to Gram staining, Catalase and sugar fermentation tests also Rap ID STR kit (Remel, USA). Standard strain of $S$. mutans ATCC $^{\mathbb{B}} 35688$ was also studied for comparison.

In order to obtain sufficient concentrations of proteins, $10^{11}$ cells of each isolate were grown in $100 \mathrm{~mL}$ Brain Heart Infusion (BHI) for $18 \mathrm{~h}$ at $37{ }^{\circ} \mathrm{C}$ with shaking (160 rpm) in a shaker incubator (Heidolph, Germany). Cells were collected by centrifugation $(10,000 \times \mathrm{x} g$ for $15 \mathrm{~min}$ ) and washed three times in $40 \mathrm{mM}$ potassium phosphate ( $\mathrm{pH} 7.5$ ) with $3 \mathrm{mM}$ dithiothreitol, $10 \mathrm{mM}$ L-cysteine $\mathrm{HCl}, 0.06 \mathrm{mM}$ MnSO4 (Selander et al., 1986). Cells were normally lysed by sonication (Hielscher, Germany) with microtip for 30 to $60 \mathrm{~s}$, with ice-bath cooling. After lysis and centrifugation at $30,000 \mathrm{x}$ g for $20 \mathrm{~min}, 0.5 \mathrm{~mL}$ of the several milliliters of lysate (supernatant) were transferred to three or four culture tubes and stored at $-20^{\circ} \mathrm{C}$ until used for electrophoresis. Protein concentrations were also determined by the Lowry method (Lowry et al., 1951).

Electrophoresis was carried out in $10 \%(\mathrm{w} / \mathrm{v})$ polyacrylamide resolving gels $(1.5 \mathrm{M}$ Tris- $\mathrm{HCl} \mathrm{pH} 8.9,10 \%$ acrylamide + bisacrylamide) and $2.5 \%$ stacking gels $(0.5 \mathrm{M}$ Tris- $\mathrm{HCl} \mathrm{pH} \mathrm{6.9,3 \%} \mathrm{acrylamide} \mathrm{+} \mathrm{bisacrylamide)} \mathrm{by} \mathrm{using}$ $0.75 \mathrm{~mm}$ thick slab gels and Tris/HCl buffer (pH 6.8). The amount of $5 \mu \mathrm{L}$ of Samples were diluted (total concentration of $50 \mathrm{~g}$ protein in diluted samples) in an equal volume of sample buffer ( $1 \mathrm{~g}$ sucrose, $500 \mu \mathrm{L} \beta$-mercaptoethanol, $0.002 \mathrm{~g}$ bromophenol blue, $1 \mathrm{~mL}$ of $1 \mathrm{M}$ Tris/HCl). A marker of known molecular mass (Fermentas SM 0661 protein ladder) was also loaded $(20 \mu \mathrm{L})$ along with the samples. The apparatus was connected with constant electric current $(30 \mathrm{~mA})$ till the bromophenol blue (BPB) reached the bottom of the plate. The gel was run in a cold room at $5{ }^{\circ} \mathrm{C}$. After running $(120 \mathrm{~min}, 30 \mathrm{~mA})$, gels were revealed for enzyme active band detection of alcohol dehydrogenase (ADH), malic enzyme (ME), glucose dehydrogenase (GDH), glucose-6-phosphate dehydrogenase (G6PD), glucosyltransferase (GTF), lactate dehydrogenase (LDH), malate dehydrogenase $(\mathrm{MDH})$, superoxide dismutase (SOD), and glutamic-oxaloacetic transaminase (GOT).

For enzymatic band revelation, stain solution [100 mL Tris Glycine buffer $1 \mathrm{X}$ pH8, the specific substrate of each enzyme, coenzyme (100 mg NAD), Dye (50 mg $\mathrm{NBT}$ ) and catalyst (20 mg PMS) and $40 \mathrm{mg} \mathrm{MgCl}$ ] was applied to the gel in an agar overlay. Gels were incubated at $37^{\circ} \mathrm{C}$ in the dark until bands appear (45-60 min). The stain solution was then poured off and fixed in a $5 \%$ acetic acid solution.

After appearing enzymic bands, they were scored according to their respective relative mobility's generating binary data (Schable et al., 1991).

Genetic diversity for a locus is calculated as $h=\left[1-\sum \mathrm{xi}^{2}\right][n /(n-1)]$, where $x_{i}$ is the frequency of $i$ th allele at the locus, $\mathrm{n}$ is the number of isolates $n /(n-1)$ is the correction for bias in small samples (Nei, 1978; Rosa et al., 2005; Selander et al., 1986).

A dendrogram was generated after the overall gel analysis using Euclidean Distance coefficient) calculated by the NTSYS 1.70 packages (Applied Biostatistics, Inc.). A tree of genetic distance was generated by the unweighted pair-group arithmetic average (UPGMA) clustering method (Rosa et al., 2005; Sneath and Sokal, 1973).

In This Study, twelve S. mutans isolates were analyzed (Table 1). Six isolates were isolated from cariessusceptible subjects and, five other were isolated from caries-free persons.

All analyzed enzyme systems (ADH, GDH, G6PD, LDH, MDH, ME, GOT, GTF) showed no activity for any $S$. mutans isolates of caries-free subject group (Table 1). Glucose-6-phosphate dehydrogenase (G6PD) showed thin band zones that did not vary among all of the $S$. mutans isolates of caries susceptible group and $\mathrm{ATCC}^{\mathbb{B}} 35688$. Two alleles (allele 1 and allele2) for G6PD were visualized in $\mathrm{C} 2$ and $\mathrm{ATCC}^{\mathbb{B}} 35688$ strains while in other isolates only the second allele was observed and no locus of G6PD was seen in caries free isolates (Figure 1). For lactate dehydrogenase (LDH), the unexpected electrophoretic bands appeared only in C1, C2 and D3 (Table 1).

All analyzed enzyme systems were active for $S$. mutans $\mathrm{C} 2$ isolated from caries susceptible subject group and $\mathrm{ATCC}^{\circledR} 35688$. For glucosyltransferase (GTF), a typical enzyme produced by $S$. mutans, the expected electrophoretic bands did not appear in all of the isolates and it is only appeared in $\mathrm{C} 2$ and $\mathrm{ATCC}^{\circledR} 35688$. The biofilm formation ability of these two isolates (C2 and $\mathrm{ATCC}^{\circledR} 35688$ ) was very high and they were classified as strongly adherent (data not shown). 
Table 1 - Electromorphotypes of $S$. mutans isolates of caries-free and caries susceptible individuals.

\begin{tabular}{|c|c|c|c|c|c|c|c|c|c|c|c|}
\hline \multirow[t]{2}{*}{ Subject } & \multirow[t]{2}{*}{ Isolate } & & \multicolumn{9}{|c|}{ Allele at enzyme locus* } \\
\hline & & & $\mathrm{MDH}$ & G6PD & GDH & ME & GTF & GOT & $\mathrm{ADH}$ & LDH & SOD \\
\hline \multirow[t]{5}{*}{ Caries-susceptible } & 1 & $\mathrm{C} 1$ & - & 2 & - & - & - & - & - & 1 & - \\
\hline & 1 & $\mathrm{C} 2$ & 1 & $1,2^{\mathrm{a}}$ & 1 & 1 & 1 & 1 & 1 & 1 & - \\
\hline & 2 & D3 & - & 2 & - & - & - & - & - & 1 & - \\
\hline & 3 & $\mathrm{~F} 4, \mathrm{~F} 5$ & - & 2 & - & - & - & - & - & - & - \\
\hline & 4 & G7 & - & 2 & - & - & - & - & - & - & - \\
\hline \multirow[t]{3}{*}{ Caries-free } & 5 & A8 & - & - & - & - & - & - & - & - & - \\
\hline & 6 & B9, B11 & - & - & - & - & - & - & - & - & - \\
\hline & 7 & P12, P13 & - & - & - & - & - & - & - & - & - \\
\hline - & - & ATCC $^{\circledR} 35688$ & 1 & 1,2 & 1 & 1 & 1 & 1 & 1 & 1 & - \\
\hline
\end{tabular}

*Ac*according to the anodal migration.

a: Two alleles (allele 1 and allele 2) for G6PD were visualized while for others only one locus was seen.

Isolates $\# \mathrm{C} 1, \# \mathrm{C} 2, \# \mathrm{D} 3, \# \mathrm{~F} 4, \# \mathrm{~F} 5$, and $\# \mathrm{G} 7$ were isolated from caries susceptible subjects; Strain \#S was $S$. mutans $\mathrm{ATCC}^{\mathbb{B}} 35668$; Slot $\mathrm{E}$ is the pure enzyme that was added as an electrophoretic control.

As it is shown in Table 1, isolate $\mathrm{C} 1$ also differed from $\mathrm{C} 2$ and they were isolated from the same individual (subject \#1) and their enzymatic patterns suggest that they belong to different clones. Indeed, average genetic diversity between both clones was determined as 0.468 . In this study, genetic diversities for the eight evaluated loci were, $0.59,0.88$, for G6PD and LDH respectively and 0.097 for other loci. The mean diversity for the loci was 0.228 .

To determine the genetic distance among isolates as well as their clustering behavior, a non-rooted dendrogram was built (Figure 2). Such tree shows that different isolates could be clustered in four different taxa with genetic distances varying from 0.2398 to 0.9592 .

All isolates from free caries subjects as listed in Table 1 belong to clade $\mathrm{C}$ as shown in Figure 2 (genetic distance $\mathrm{d} \geq 0.4796$ ).

Although in different taxa, different isolates of same individuals (patients \#3, \#6 and \#7) presented no divergences $(d=0.0000)$. Patient $\# 1$, however, presented two isolates separated one to each other with a $d=0.9592$, showing that more than one clonal type can be found in a same individual.

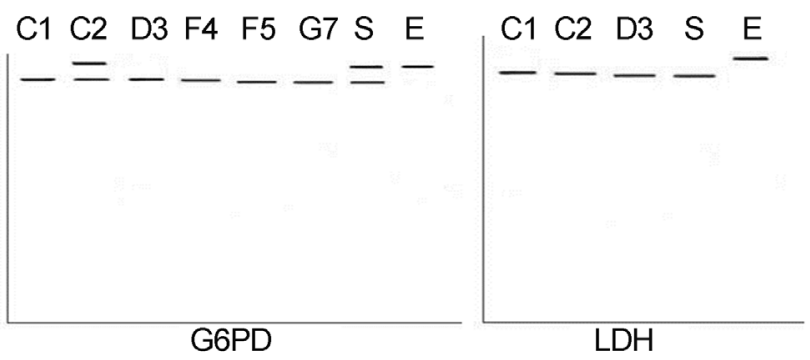

Figure 1 - Multilocus enzyme electrophoresis analysis of S. mutans isolates of caries free $\&$ caries susceptible subjects.
The differentiation ability of MLEE for cariogenic and non cariogenic $S$. mutans isolates was confirmed in this study. Isolates of caries susceptible group differed from isolates of caries free group.

According to the results, it is evident that caries-susceptible subjects bear more genotypes than caries-free. It is in agreement with earlier reports (Alaluusua et al., 1996; Napimoga et al., 2004). Redmo-Emanuelsson et al. (2003), in a study enrolling young adults (mean age of 25.2 years) found a maximum of seven genotypes in subjects who had previous caries experience and Napimoga et al. (2004) found a maximum of eleven and eight genotypes in caries-active subjects using MLEE and AP-PCR respectively.

We obtained up to three genotypes in caries-susceptible subjects (4 subjects; 7 isolates) using MLEE. In contrast, the results of Kreulen et al. (1997) showed a negative relationship between caries activity and genotype diversity. Redmo-Emanuelsson et al. (2003) suggested that the larger number of genotypes found could be because of the larger number of isolates analyzed, which increases the possibility of detecting different genotypes.

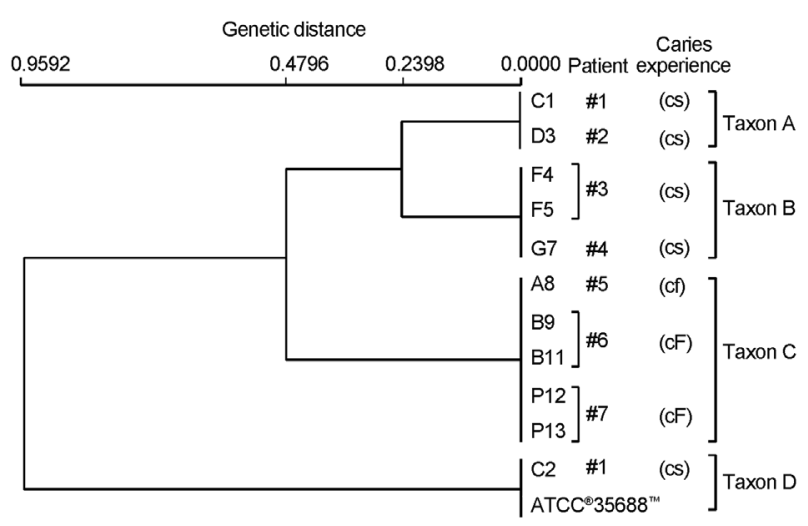

Figure 2 - Non-rooted dendrogram clustering isolates of $S$. mutans from caries-free (CF) and caries-susceptible (CS) patients in different taxa in function of their isozymic profiles. 
In this study, all analyzed enzyme systems revealed no activity for any $S$. mutans isolates of caries free subject group (3 subject, 5 isolates) so, they belong to one clade. Perhaps, such enzymes are either produced in smaller quantities than the method can detect or they are not produced by those isolates. Alaluusua et al. (1996) related that six caries-free children (3 to 7 strains per volunteer) only harboured one ribotype of S.mutans . According to these, it is probable that from plaque samples of caries free subjects the only primary strains were found and other strains, if they existed were below the detection level.

Getting activity for G6PD (in $S$. mutans isolates of caries susceptible group and $\mathrm{ATCC}^{\circledR} 35688$ ) and LDH (in $\mathrm{C} 1, \mathrm{C} 2$ and D3) in this study was in contrast with previous researches that showed no activity for the major part of dehydrogenases (ADH, GDH, G6PD, LDH, MDH, ME) in S. mutans strains (Napimoga et al., 2004; Rosa et al., 2006). These differences are probably due to the $\mathrm{pH}$, type of buffer system used in preparation of enzyme extract or type and concentration of used gel. Occasionally, the relative mobilities of certain electromorphs are reversed in different buffer system (Selander et al., 1986). According to Wunder and Bowen (2000), glucosyltransferases are enzymes that act at extracellular environment. This may, at least in part, explain why glucosyltransferase activity was not observed in all of the cases and it is only appeared in $\mathrm{C} 2$ and $\mathrm{ATCC}^{\circledR} 35688$.

A non-rooted dendrogram was shown that different isolates of this study could be clustered in four different taxa. All isolates from three caries-susceptible patients were grouped in a single taxon (taxon C). Patient \#1, however, presented two isolates separated one to each other $(d=0.9592)$, showing that more than one clonal type can be found in a same individual. Rosa et al. (2006) also could isolate two clusters of $S$. mutans isolates from a same individual, and their enzymatic patterns suggest that they belong to different clones. The isolates of caries free subjects, presented no divergences $(d=0.0000)$ although they were isolated from non-related individuals.

In parallel to the discrimination ability, MLEE has proven to be a useful tool for establishing genetic diversity, even in small or subdivided (Rosa et al., 2005) populations. This method detects allelic frequencies prompter than other methodologies, such as RAPD and RFLP. These facts support the premise that MLEE may be used in surveys in which intra-species determination of $S$. mutans is required. In conclusion, the results here presented support the proposition of MLEE employment for clonal differentiation of Streptococcus mutans. Three clonal types and one clonal type were observed in caries-susceptible and caries-free subjects, respectively.

\section{Acknowledgments}

This work is the part of research project that was supported by Islamic Azad University Khorasgan- Isfahan branch. The authors thank the President, and the Educational and the Research Vice- Presidents of Islamic Azad University, Khorasgan branch, Isfahan, Iran (Dr A.A. Foroughiabari, Dr M. Hoodaji and Dr P. Najafi) for their help and support.

\section{References}

Alaluusua S, Kleemola-Kujala E, Nystrom M (1987) Caries in the primary teeth and salivary Streptococcus mutans and lactobacillus levels as indicators of caries in permanent teeth. Paediatr Dent 9:126-130.

Alaluusua S, Matto J, Gronroos L, Innila S, Torkko H, Asikainen S (1996) Oral colonization by more than one clonal type of mutans streptococci in children with nursing-bottle dental caries. Arch Oral Biol 41:167-173.

Arakawa H, Karasawa K, Igarashi T, Suzuki S, Goto N, Maeda M (2004) Detection of cariogenic bacteria genes by a combination of allele-specific polymerase chain reactions and a novel bioluminescent pyrophosphate assay. Anal Biochem 15:296-302.

Araújo JV, Junghans TG, Alfenas AC, Gomes AP (1997) Isoenzyme analysis of Arthrobotrys a nematode-trapping fungus. Braz J Med Biol Res 30:1149-1152.

Baca P, Castillo AM, Baca AP, Liebana MJ, Junco P, Liebana J (2008) Genotypes of Streptococcus mutans in saliva vs. dental Plaque, Arch Oral Boil 53:751-754.

Baptist JN, Shaw CR, Mandel M (1971) Comparative zone electrophoresis of enzymes of Pseudomonas solanacearum and Pseudomonas cepacia. J Bacteriol 108:799-803.

Becker MR, Paster BJ, Leys EJ, Moeschberger ML, Kenyon SG, Galvin JL, Boches SK, Dewhirst FE, Griffen AL (2002) Molecular analysis of bacterial species associated with childhood caries. J Clin Microbiol. 40:1001-1009.

Beighton D, Rippon HR, Thomas HEC (1987) The distribution of Streptococcus mutans serotypes and dental caries in a group of 5- to 8-year-old Hampshire schoolchildren. Braz Dent J 162:103-106.

Carlsson P, Olsson B, Bratthall D (1985) The relationship between the bacterium Streptococcus mutans in the saliva and dental caries in children in Mozambique. Arch Oral Biol 30:265-268.

Caugant DA, BfVre K, Gaustad P, Bryn K, Holten E, HfIby EA (1986) Multilocus genotypes determined by enzyme electrophoresis of Neisseria meningitidis isolated from patients with systemic disease and from healthy carriers. J Gen Microbiol 132:641-652.

Caulfield PW, Walker TM (1989) Genetic diversity within Streptococcus mutans evident from chromosomal DNA restriction fragment polymorphism. J Clin Microbiol 27:274-278.

Gilmour MN, Whittam TS, Kilian M, Selander RK (1987) Genetic relationships among the oral streptococci. J Bacteriol 169:5247-5257.

Gronroos L, Alaluusua S (2000) Site specific oral colonization of mutans streptococci detected by arbitrarily primed PCR fingerprinting. Caries Res 34:474-80.

Jordan C, LeBlanc DJ (2002) Influences of orthodontic appliances on oral populations of mutans streptococci. Oral Microbiol Immunol 17:65-71.

Kamiya RU, Napimoga MH, Rosa RT, Hofling JF, Gonclves RB (2005) Mutacin production in Streptococcus mutans geno- 
types isolated from caries-affected and caries-free individuals. Oral Microbiol Immunol 20:20-24.

Kreulen CM, de Soet HJ, Hogeveen R, Veerkamp JS (1997) Streptococcus mutans in children using nursing bottles. ASDC J Dent Child 64:107-111.

Li M, Lai G, Wang J (2011) The prevalence of virulent clonal strains of mutans streptococci in vivo and co-culture succession of the strains in vitro. Open J Stomatol 1:18-24.

Lowry OH, Rosebrough NJ, Farr AL, Randall RJ (1951) Protein measurement with the Folin phenol reagent. J Biol Chem 193:266-267.

Matee MIN, Mikx FHM, de Soet JS, Masell SY, de Graff J, van Palenstein Helderman WH (1993) Mutans streptococci in caries-active and caries-free infants in Tanzania. Oral Microbiol Immunol 8:322-324.

Meloni BP, Lymberi AJ, Thompson RCA (1988) Isoenzyme electrophoresis of 30 isolates of Giardia from humans and felines. Am J Trop Med Hyg 38:65-73.

Napimoga MH, Kamiya RU, Rosa TR, Rosa EAR, Hofling JF (2004) Genotypic diversity and virulence traits of Streptococcus mutans in caries-free and caries active Individuals. J Med Microbiol 53:697-703.

Naumov GI, Naumova ES, Sniegowiski PD (1997) Differentiation of European and Far East Asian populations of Saccharomyces paradoxus by allozyme analysis. Int J Syst Bacteriol 47:341-344.

Nei M (1978) Estimation of average heterozygocity and genetic distance from a small samole of individuals. Genetics 89:583-90.
O'Brien SJ, Simonson JM, Grabowski MW, Barile MF (1981) Analysis of multiple isoenzyme expression among twentytwo species of Mycoplasma and Acholeplasma. J Bacteriol 146:222-232.

Redmo Emanuelsson IM, Carlsson P, Hamberg K, Bratthall D (2003) Tracing genotypes of mutans streptococci on tooth sites by random amplified polymorphic DNA (RAPD) analysis. Oral Microbiol Immunol 18:24-29.

Rosa RT, Napimoga MH, Hofling JF, Gonçalves RB, Rosa EAR (2006) Clonal characterization of Streptococcus mutans strains by multilocus enzyme electrophoresis. Braz J Microbiol 37:17-19.

Rosa RT, Napimoga MH, Hofling JF, Gonçalve RB, Rosa EAR (2005) Clonal Diversity of Streptococcus Clarke (1924) in caries-free adults. Estud Biol 27:49-51.

Schable B, Villarino ME, Favero MS (1991) Application of multilocus enzyme electrophoresis to epidemiologic investigations of Xanthomonas maltophilia. Infect Control Hosp Epidemiol 12:163-167.

Selander RK, Caugant DA, Ochman H, Musser JM, Gilmour MN, Whittam TS (1986) Methods of multilocus enzyme electrophoresis for bacterial population genetics and systematics. Appl Environ Microbiol 51:873-884.

Sneath PHA, Sokal RQ (1973) Numerical taxonomy. San Francisco: Freeman, $482 \mathrm{pp}$.

Wunder D, Bowen WH (2000) Effects of antibodies to glucosyltransferase on soluble and insolubilized enzymes. Oral Dis 6:289-296.

All the content of the journal, except where otherwise noted, is licensed under a Creative Commons License CC BY-NC. 